\title{
Morpho-physiological Characteristics and Molecular Markers of Maize Crosses Under Multi-location Evaluation
}

\author{
Vasileios A. Greveniotis ${ }^{1,2}$, Veronica S. Giourieva ${ }^{3}$, Elisavet C. Bouloumpasi ${ }^{4,5}$, Evangelia J. Sioki ${ }^{6}$ \\ $\&$ Paraskevi G. Mitlianga ${ }^{4}$ \\ ${ }^{1}$ Department of Agricultural Technology, Technological Education Institute of Thessaly, Larissa, Greece \\ ${ }^{2}$ Department of Agricultural Development, Democritus University of Thrace, Orestiada, Greece \\ ${ }^{3}$ Department of Botany, School of Biology, Aristotle University of Thessaloniki, Thessaloniki, Greece \\ ${ }^{4}$ Department of Agricultural Technologists, School of Agricultural Technology, Food Technology and Nutrition, \\ Western Macedonia University of Applied Sciences, Florina, Greece \\ ${ }^{5}$ Department of Food Science and Technology, School of Agriculture, Aristotle University of Thessaloniki, \\ Thessaloniki, Greece \\ ${ }^{6}$ Department of Agricultural Economics, Aristotle University of Thessaloniki, Thessaloniki, Greece \\ Correspondence: Vasileios A. Greveniotis. Department of Agricultural Technology, Technological Education \\ Institute of Thessaly, Larissa, Greece. Tel: 30-241-068-4365. E-mail: vgreveni@mail.com; vgreveni@teilar.gr
}

Received: June 25, 2018

Accepted: August 6, 2018

Online Published: October 15, 2018

doi:10.5539/jas.v10n11p79

URL: https://doi.org/10.5539/jas.v10n11p79

\begin{abstract}
The superior lines A1, A2, B1 and B2, which were developed from honeycomb evaluation in two different environments (A and $B$ ), were crossed in the field in environment $A$ to obtain the following six crosses $A 1 \times A 2$, $\mathrm{A} 1 \times \mathrm{B} 1, \mathrm{~A} 1 \times \mathrm{B} 2, \mathrm{~A} 2 \times \mathrm{B} 1, \mathrm{~A} 2 \times \mathrm{B} 2$ and $\mathrm{B} 1 \times \mathrm{B} 2$. Measurements performed in a RCB design included quantitative and quality characteristics and molecular data based on ISSR molecular markers. The objective of this study was to investigate the presence of variation of quantitative, quality and molecular characteristics among crosses of superior selected lines that developed after multi-location selection.

Principal component and cluster analyses were used for grouping genotypes, while correlations were performed to investigate relations between all quantitative and quality characteristics. According to PCA analysis, the six newly-developed crosses, which were evaluated in different environments, showed measurable distances between the identical lines $(\mathrm{B} 1 \times \mathrm{B} 2(\mathrm{~A})$ and $\mathrm{B} 1 \times \mathrm{B} 2(\mathrm{~B}))$ suggesting genotype-environment interaction. Also, cluster analysis showed that some crosses, such as $\mathrm{A} 1 \times \mathrm{B} 2(\mathrm{~A})$ and $\mathrm{A} 1 \times \mathrm{B} 2(\mathrm{~B})$, are grouped in separate and distinct clusters indicating that dissimilar developmental environments may cause changes in quantitative traits. This may be due to the origin of the selected lines, since they were developed in different locations. Lines developed in the same location gave crosses that had similar behavior in the two locations. Also, it is clear that a kind of gene fixation is apparent from the $\mathrm{C} 3$ cycle in $\mathrm{A} 1 \mathrm{xA} 2$ cross, since it is close (and similar) to the $\mathrm{C} 4$ cross. Crosses including A2 line showed a greater stability in both environments.
\end{abstract}

Keywords: evaluation, ISSR, crosses, principal component analysis

\section{Introduction}

Maize (Zea mays L.) is one of the three most important crops worldwide, accounting for 40 percent of the world's cereal food production, because of its high adaptability in diverse environments (Koutsika-Sotiriou, 1999). It is cultivated in Greek regions of Macedonia, Thrace, Thessaly and West Hellas.

Plant breeding aims at crop yield potential and quality improvement by exploiting two types of vigor. One vigor is expressed in homozygous condition while the other in heterozygous condition (Fasoulas, 1988, pp. 16-18; Ipsilandis \& Koutsika-Sotiriou, 2000). The term "inbred vigor" was introduced by Fasoulas $(1973,1974)$ to depict the superiority of recombinant lines over their original parental lines and also, the homozygote superiority over heterogeneity and crosses. Genome integration and genetic gain presupposes the fixation of desirable genes and the removal of deleterious genes (Ipsilandis \& Koutsika-Sotiriou, 2000; Fasoula \& Fasoula, 2005). 
Maize kernel composition is important for human and animal nutrition (Flint-Garcia, Bodnar, \& Scott, 2009). The kernel composition mean values for the commodity yellow dent corn on a dry matter basis are $71.7 \%$ starch, 9.5\% protein, $4.3 \%$ oil, 1.4\% ash, and 2.6\% sugar (Watson, 2003). Kernel weight is an important component of maize yield in relation to genotypes across environments (Jones \& Simmons, 1983; Borrás, Zinselmeier, Senior, Westgate, \& Muszynski, 2009).

Characterization of maize breeding lines using simple sequence repeats (SSR) and inter-simple sequence repeat (ISSR) markers has been performed in the past (Žiarovska et al., 2013). The level of polymorphism reported ranged from 73 to $77 \%$ and the SSR polymorphism found among 45 maize genotypes reached $100 \%$. Idris et al. (2012) recorded 69\% polymorphism among maize genotypes based on the same molecular markers. Žiarovska et al. (2013) reported 6.8 markers per primer, while Warburton et al. (2001) reported 6.3 markers per primer. SSR and ISSR markers have been used in other species in order to identify and utilize genetic variation (Bredemeijer, Arens, Wouters, Visser, \& Vosman, 1998; Gilbert, Lewis, Windson, \& Caligari, 1999; Prevost \& Wilkinson 1999; Huang \& Sun 2000; Métais, Aubry, Hamon, Jalouzot, \& Peltier, 2000; Prasad, Varshney, Roy, Balyan, \& Gupta, 2000). PCR-based SSR markers are very powerful as they are co-dominant and multi-allelic, as well as highly polymorphic. However, SSR markers are costly and usually demand long time to be developed, which are major drawbacks for their use. In contrast, ISSR markers are universal, thus, there is no need for prior sequence knowledge and can be directly applied to any plant species. Thus, both systems have pros and cons, which means that there is no single dominant marker system suitable for universal use that meets all the user's needs, however ISSR markers are considered to be quick, robust and provide more informative data sets with less effort and cost than other dominant molecular marker techniques (Salimath, de Oliveira, Godwin, \& Bennetzen, 1995; Yang, de Oliveira, Godwin, Schertz, \& Bennetzen, 1996; Godwin, Aitken, \& Smith, 1997).

Principal component analysis and cluster analysis are the most used multivariate techniques for morphological grouping of genotypes (Peeters \& Martinelli, 1989; Mohammadi \& Prasanna, 2003). With regard to maize, Khodarahmpour (2012) found three main clusters of maize hybrids based on 30 quality and quantitative traits.

The objective of this study was to investigate the presence of variation of quantitative, quality and molecular characteristics among crosses of superior selected lines that developed after multi-location selection.

\section{Materials and Methods}

\subsection{Plant Material, Selection and Evaluation Methods}

Selection started in 2007 in the F2 generation (C0) of the commercial F1 hybrid Costanza and continued for 5 cycles (up to C4). Selection was applied in two agro-climatically contrasting environments, environment A (Florina, Northwestern Greece, altitude $705 \mathrm{~m}$, soil classification SL, soil pH =6.25) and B (Trikala, Central Greece, altitude $120 \mathrm{~m}$, soil classification SCL, $\mathrm{pH}=8$ ). Superior plants and lines (A and B according to the environment) were selected on the basis of the two selection equations (Fasoula, 2006, 2013).

In 2012, the best two lines A1 and A2 were selected after the 5-year evaluation (2007-2011) in environment A and the best two lines B1 and B2 were also selected in environment B. These superior lines A1, A2, B1, and B2 were crossed in the field in environment $A$ to obtain the following six crosses $A 1 \times A 2, A 1 \times B 1, A 1 \times B 2, A 2 \times B 1$, $\mathrm{A} 2 \times \mathrm{B} 2$ and $\mathrm{B} 1 \times \mathrm{B} 2$. Rows were spaced $1 \mathrm{~m}$ apart and the usual crossing procedure was followed. The crosses were performed in August 2012.

In 2013, the six newly-developed crosses $(\mathrm{A} 1 \times \mathrm{A} 2, \mathrm{~A} 1 \times \mathrm{B} 1, \mathrm{~A} 1 \times \mathrm{B} 2, \mathrm{~A} 2 \times \mathrm{B} 1, \mathrm{~A} 2 \times \mathrm{B} 2$ and $\mathrm{B} 1 \times \mathrm{B} 2)$ along with $\mathrm{F} 1$ hybrid Costanza were sown in randomized complete block (RCB) trials in both environments $\mathrm{A}$ and $\mathrm{B}$ (Table 1). For environment A, an additional check material accompanied Costanza: a cross formed and selected from the previous generation of the two best experimental lines in environment A (A1 $\times$ A 2 in $C 3$ cycle). Row spacing was $0.75 \mathrm{~m}$. 
Table 1. The genetic materials used in experiments in the two environments

\begin{tabular}{lll}
\hline 1 & Environment B & $\mathrm{A} 1 \times \mathrm{A} 2$ \\
\hline 2 & Environment B & $\mathrm{A} 1 \times \mathrm{B} 1$ \\
3 & Environment B & $\mathrm{A} 1 \times \mathrm{B} 2$ \\
4 & Environment B & $\mathrm{A} 2 \times \mathrm{B} 1$ \\
5 & Environment B & $\mathrm{B} 1 \times \mathrm{B} 2$ \\
6 & Environment B & $\mathrm{A} 2 \times \mathrm{B} 2$ \\
7 & Environment B & $\mathrm{F} 1 \mathrm{Costanza}$ \\
8 & Environment A & $\mathrm{A} 1 \times \mathrm{A} 2$ \\
9 & Environment A & $\mathrm{A} 1 \times \mathrm{B} 1$ \\
10 & Environment A & $\mathrm{A} 1 \times \mathrm{B} 2$ \\
11 & Environment A & $\mathrm{A} 2 \times \mathrm{B} 1$ \\
12 & Environment A & $\mathrm{B} 1 \times \mathrm{B} 2$ \\
13 & Environment A & $\mathrm{A} 2 \times \mathrm{B} 2$ \\
14 & Environment A & $\mathrm{F} 1 \mathrm{Costanza}$ \\
15 & Environment A & $\mathrm{A} 1 \times \mathrm{A} 2(\mathrm{C} 3)$ \\
\hline
\end{tabular}

\subsection{Measurements Procedure}

In 2014, measurements of quantitative and quality characteristics were conducted.

\subsubsection{Quality Characteristics}

Quality characteristics measured were: seed protein, seed oil, moisture, $\mathrm{pH}$, ash content and color parameters. Milling of kernel samples was performed prior to the analyses.

Ash content was determined according to AACC Method 08-01 (AACC, 1983a). Moisture content was determined according to AACC Method 44-15A (AACC, 1983b). Total nitrogen was determined by a Kjeldahl method (modified AACC Method 46-12 (AACC, 1983c)) and the factor used was 6.25 for the calculation of protein content. Crude fat was determined by Soxhlet extraction with petroleum ether using a Soxtherm SOX 416 Macro (Gerhardt) based on AACC Method 30-25 (AACC, 1983d). The pH values were determined at $20{ }^{\circ} \mathrm{C}$.

Color parameters $\left(\mathrm{L}^{*}:\right.$ luminosity, $\mathrm{a}^{*}$ : redness and $\mathrm{b}^{*}$ : yellowness) were measured using a Minolta Chroma Meter (model CR-410) (Minolta Camera Co, Osaka, Japan) with a $10 \mathrm{~mm}$ measuring area (aperture) and illuminant source $\mathrm{C}$.

\subsubsection{Quantitative Characteristics}

Kernel weight: This was evaluated by counting and weighing 1000 maize grains (thousand-kernel weight). The weight of kernels per 100 litres was also calculated (hectoliter weight).

Kernel size: This was measured in mm by randomly selecting 10 kernels and measuring the three major axes, namely: length, width and depth with a Vernier Calliper.

Ear length, Ear diameter, Spindle diameter: The dimensions were measured in $\mathrm{mm}$ by the ruler and the calliper, as a mean of 10 ear observation for each genetic material.

Number of grain rows per ear: Number of rows was counted by eye, as a mean of 10 ear observation for each genetic material.

\subsubsection{Molecular Analysis With ISSR Markers}

The genetic diversity among the maize lines was studied using ISSR markers. Genomic DNA was isolated using the procedure described by J. J. Doyle and J. L. Doyle (1987) and was quantified using UV-Spectrophotometer Ultrospec 2000 (Pharmacia Biotech, Cambridge, UK). Samples were diluted to $20 \mathrm{ng} / \mathrm{uL}$ final concentration. Polymerase chain reaction (PCR) for ISSR analysis was performed in a total volume $20 \mathrm{uL}$. Each tube contained 20 ng DNA, 5 U/uL DNA Taq polymerase (Invitrogen, Carlsbad, CA), $1 \times$ PCR buffer, $0.2 \mathrm{mM} \mathrm{dNTPs,} 1.5 \mathrm{mM}$ $\mathrm{MgCl}_{2}$ and $0.2 \mathrm{uM}$ of each primer.

Six oligonucleotide primers complementary to simple sequence repeats were used for the study of inter-simple sequence repeats (UBC807, UBC811, UBC824, UBC827, UBC834, UBC841). The used primers are shown in Table 2. PCR amplification was performed in Veriti 96 canals (Applied Biosystems, CA, USA) as follows: an initial denaturation at $95{ }^{\circ} \mathrm{C}$ for $5 \mathrm{~min}$, followed by 40 cycles of $30 \mathrm{~s}$ at $95^{\circ} \mathrm{C}$ for denaturation, $1 \mathrm{~min}$ and $30 \mathrm{~s}$ at 
54-58 ${ }^{\circ} \mathrm{C}$ (depending on the primer used) for annealing and $1 \mathrm{~min}$ and $30 \mathrm{~s}$ at $72{ }^{\circ} \mathrm{C}$ for elongation. Final extension was performed in 5 min step at $72{ }^{\circ} \mathrm{C}$. PCR products were separated by electrophoresis in $1.5 \% \mathrm{w} / \mathrm{v}$ agarose gel and stained with ethidium bromide.

Table 2. ISSR primers used in this study

\begin{tabular}{ll}
\hline Primer name & Sequence (5'-3') \\
\hline UBC834 & AGAGAGAGAGAGAGAGT \\
UBC824 & GAGAGAGAGAGAGAGAC \\
UBC841 & ACACACACACACACACACT \\
UBC807 & ACACACACACACACACG \\
UBC811 & AGAGAGAGAGAGAGAGYT \\
UBC827 & GAGAGAGAGAGAGAGAYC \\
\hline
\end{tabular}

To check the genetic diversity among the maize lines, which were grown in different environments, the bands of each primer were scored in an Excel 2013 file. Because ISSR markers are dominant, each band represents a phenotype at a single biallelic locus. The presence of a band was marked as 1 and the absence as 0 while the absence of an amplicon was marked as -1. A binary qualitative data matrix was formed. The data matrix was used to obtain the Principal of Coordinates Analysis (PCoA) using GenAlEx6.5 (Genetic Analysis in Excel, Peakall \& Smouse 2012). Gene diversity and Shannon's diversity index (I) was used as a measure of within-population variability.

The aim of Principal Component Analysis (PCA) use is to establish the number of main factors that could be used in order to decrease the necessary numbers of effective parameters for the discrimination of genotypes. Moreover, this method could allow the correlation of phenotypic traits with genetic linkage between loci controlling traits (Iezzoni \& Pritts 1991; Rakonjac, Aksic, Nikolic, Milatovic, \& Colic, 2010).

Cluster analysis was used in order to separate the available data into groups of increasing dissimilarity. The Euclidean distance was used as a metric to measure the genetic dissimilarity of the 15 maize crosses, based on the combined quantitative and quality data and Ward's method was used for the agglomeration. Correlations were based on the procedure described by Steel and Torrie (1980), involving all quantitative and quality characteristics. The Pearson coefficient was used to measure the correlation between all quantitative and quality traits.

\section{Results and Discussion}

\subsection{Qualitative and Quantitative Multivariate Analyses}

Seventeen quality and quantitative traits were measured and the descriptive statistics of minima, maxima, means and standard deviations were recorded (Table 3). The results indicate morpho-physiological diversity. Some quality and quantitative traits display high coefficient of variation (CV) values: seed oil (18.92), ash content (11.75) and spindle diameter (10.63). The means of quality and quantitative were: for moisture $12.230 \%$, for seed oil $2.96 \%$, for ash $1.243 \%$, for seed protein $8.498 \%$, pH $6.5, L^{*} 84.134$, a* $-0.909, b^{*} 23.089$, ear length $201.27 \mathrm{~mm}$, ear diameter $49.28 \mathrm{~mm}$, number of grain rows per ear 15.387 , spindle diameter $26.811 \mathrm{~mm}$, seed length $12.649 \mathrm{~mm}$, seed width $8.883 \mathrm{~mm}$, seed thickness $4.664 \mathrm{~mm}$, thousand-kernel weight $356.192 \mathrm{~g}$ and hectolitre weight $70.519 \mathrm{~kg}^{-1} \mathrm{l}^{-1}$. Nuss and Tanumihardjo (2010) reported a typical kernel composition of: $9.5 \%$ protein, $4.5 \%$ oil, $1.5 \%$ ash, a little higher in comparison to our findings, even though kernel moisture content is a characteristic that depends on the environmental conditions at harvest with usually high CV (Jaradat \& Goldstein, 2013). In our dataset CV for moisture content was relative low, indicating proper and homogeneous drying at harvest. Khodarahmpour (2012), reported $24.7 \%$ moisture, 30 grains per row, 14 rows per ear, ear diameter $4.1 \mathrm{~cm}$, spindle diameter $2.4 \mathrm{~cm}$, grain width $0.44 \mathrm{~cm}$, grain diameter $0.68 \mathrm{~cm}$, thousand-kernel weight $334 \mathrm{~g}$ and hectolitre weight $701.4 \mathrm{gl}^{-1}$.

Many references showed that genetic improvement of single-cross hybrids has been associated with increased tolerance to various biotic and abiotic stress factors (Duvick \& Cassman, 1999; Tollenaar, Ying, \& Duvick, 2000; Tollenaar \& Lee, 2002; Duvick, 2005). According to Fasoulas (1993, pp. 111-114), high CV values indicate such behavior, i.e. increased influence of the environment. Seed oil and ash content with increased CVs are subjected to high environmental pressures. 
According to Pearson coefficient, some traits showed a strong linear correlation (Table 4). The highest significant positive correlation was between hectolitre weight and $b^{*}(0.896)$, spindle diameter and ear diameter (0.859), and number of grains rows per ear and ear diameter (0.730). On the other hand, there were also high, significant, negative correlations like: $\mathrm{L}^{*}$ and ash content $(-0.627)$ and number of grain rows per ear and seed width (-0.634). Kernel colour usually exhibits strong relationship with other components of kernel (Kaur, Singh, \& Rana, 2010; Jaradat \& Goldstein, 2013). Rahman, Mukul, Quddus, Hassan, \& Haque (2015) found no significant correlations between quantitative traits except for ear length with ear diameter.

According to the dendrogram (Figure 1), based on the quantitative traits, hybrids are differentiated into three main clusters. Some crosses, such as $\mathrm{A} 1 \times \mathrm{B} 2(\mathrm{~A})$ and $\mathrm{A} 1 \times \mathrm{B} 2(\mathrm{~B})$ are grouped in different and distinct clusters indicating that different developmental environments may cause changes in quantitative traits. This may be due to the different origin of the selected lines, since they were developed in different locations. Lines developed in the same location, gave crosses that had similar behavior in the two locations (like A1 $\times \mathrm{A} 2$ ). Also, it is clear that a kind of gene fixation is apparent from the $\mathrm{C} 3$ cycle in $\mathrm{A} 1 \times \mathrm{A} 2$ cross since it is close (and similar) to the $\mathrm{C} 4$ cross. On the opposite, crosses between lines of different locations showed greater distances in the two different locations, as was also reported by Shehzad, Okuizumi, Kawase, and Okuno (2009) and Ezzat, Ali and Mahmoud (2010) for sorghum. Crosses, including A2 line, showed a greater stability in the two areas. Additionally, it is also possible that increased stability of some crosses may be due to accumulation of favorable additive genes because of the certain breeding method of line selection (Fasoulas, 1988, pp. 54-56; Ipsilandis \& Koutsika-Sotiriou, 2000). Khodarahmpour (2012), found three main clusters of maize hybrids, based on 30 qualitative and quantitative traits. The first one included most of the hybrids. Our findings from cluster analysis were confirmed by PCA analysis of quantitative traits (Figure 2). The plot grouped the crosses according to their phenotypic resemblance and morphological characteristics. The first two axis of PCA explained $49.58 \%$ of the total variation among the 15 crosses, while the first axis explained the $29.43 \%$ of the variation. The distribution of crosses represents the phenotypic variation existing among the crosses and also shows how extensively spread they are along both axes. There was found a significant grouping of phenotypic traits which contribute to seed yield and seed quality, characteristics which might be helpful for plant breeding. For instance, to generate high yield and superior quality lines, cross combinations could be performed between crosses with high ear diameter, spindle diameter, hectolitre weight and low pH. F1 commercial maize hybrid Costanza was grouped alone. The most significant traits of our datasets were revealed by PCA analysis, which allows the multivariate statistical analysis. Using Kaiser's criterion ("Eigenvalue" > 1) (Kaiser, 1958), the dimension implied by the 17 quantitative and qualitative traits to six components that explained the $89.155 \%$ of the total variation was reduced (Figure 3 and Table 5). Hafiz, Jehanzeb, Ejaz-Ul-Hasan Tahira and Tariq (2015) reported that principal component (PC) analysis showed that the first 4 PC factors had Eigen value $>1$, explaining satisfactory from $86.7 \%$ and $88.4 \%$ of the total variation. Using cluster analysis, they classified 40 maize accessions into four divergent groups.

Table 3. Quality and quantity calculations of 17 characteristics of maize crosses

\begin{tabular}{llllll}
\hline Variable & Minimum & Maximum & Mean & Std. deviation & CV (\%) \\
\hline Moisture & 11.720 & 12.970 & 12.230 & 0.439 & 3.59 \\
Seed oil & 2.172 & 4.477 & 2.960 & 0.560 & 18.92 \\
Ash content & 1.062 & 1.464 & 1.243 & 0.146 & 11.75 \\
Seed protein & 7.413 & 9.884 & 8.498 & 0.616 & 7.25 \\
pH. & 6.330 & 6.720 & 6.507 & 0.113 & 1.74 \\
$\mathrm{~L}^{*}$ & 78.910 & 86.320 & 84.134 & & \\
$\mathrm{a}^{*}$ & -1.810 & 0.200 & -0.909 & & \\
$\mathrm{~b}^{*}$ & 15.360 & 28.820 & 23.089 & & 7.73 \\
Ear length & 180.00 & 238.00 & 201.27 & 1.556 & 6.26 \\
Ear diameter & 42.445 & 52.590 & 49.280 & 3.085 & 10.63 \\
Number of grain rows per ear & 13.000 & 18.000 & 15.387 & 1.150 & 6.85 \\
Spindle diameter & 20.750 & 30.168 & 26.811 & 2.851 & 3.65 \\
Seed length & 11.750 & 14.240 & 12.649 & 0.867 & 4.63 \\
Seed width & 8.130 & 9.450 & 8.883 & 0.324 & 9.10 \\
Seed thickness & 4.230 & 5.000 & 4.664 & 0.216 & 4.64 \\
Thousand-kernel weight & 302.260 & 403.990 & 356.192 & 32.398 & 3.272 \\
Hectoliter weight & 63.100 & 75.140 & 70.519 & & \\
\hline
\end{tabular}


Table 4. Correlation coefficients between 17 quantitative and quality traits

\begin{tabular}{|c|c|c|c|c|c|c|c|c|c|c|c|c|c|c|c|c|c|}
\hline Variables & Moisture & $\begin{array}{l}\text { Seed } \\
\text { oil }\end{array}$ & $\begin{array}{l}\text { Ash } \\
\text { content }\end{array}$ & $\begin{array}{l}\text { Seed } \\
\text { protein }\end{array}$ & $\mathrm{pH}$ & $\mathrm{L}^{*}$ & $\mathrm{a}^{*}$ & $\mathrm{~b}^{*}$ & $\begin{array}{l}\text { Ear } \\
\text { length }\end{array}$ & $\begin{array}{l}\text { Ear } \\
\text { diameter }\end{array}$ & $\begin{array}{l}\text { Number of } \\
\text { grain rows } \\
\text { per year }\end{array}$ & $\begin{array}{l}\text { Spindle } \\
\text { diameter }\end{array}$ & $\begin{array}{l}\text { Seed } \\
\text { length }\end{array}$ & $\begin{array}{l}\text { Seed } \\
\text { width }\end{array}$ & $\begin{array}{l}\text { Seed } \\
\text { thickness }\end{array}$ & $\begin{array}{l}\text { Thousand- } \\
\text { Kernel } \\
\text { weight }\end{array}$ & $\begin{array}{l}\text { Hectoliter } \\
\text { weight }\end{array}$ \\
\hline Moisture & 1 & & & & & & & & & & & & & & & & \\
\hline Seed oil & -0.091 & 1 & & & & & & & & & & & & & & & \\
\hline Ash content & -0.008 & 0.027 & 1 & & & & & & & & & & & & & & \\
\hline Seed protein & -0.456 & 0.349 & 0.495 & 1 & & & & & & & & & & & & & \\
\hline $\mathrm{pH}$ & 0.078 & 0.425 & -0.229 & -0.159 & 1 & & & & & & & & & & & & \\
\hline $\mathrm{L}^{*}$ & 0.311 & -0.213 & -0.627 & -0.448 & 0.171 & 1 & & & & & & & & & & & \\
\hline$a^{*}$ & 0.15 & 0.406 & 0.631 & 0.28 & 0.225 & -0.484 & 1 & & & & & & & & & & \\
\hline $\mathrm{b}^{*}$ & -0.508 & 0.532 & -0.528 & 0.149 & 0.425 & 0.197 & -0.24 & 1 & & & & & & & & & \\
\hline Ear length & 0.047 & 0.614 & 0.261 & 0.217 & -0.051 & -0.465 & 0.557 & 0.188 & 1 & & & & & & & & \\
\hline Ear diameter & 0.339 & -0.127 & 0.201 & 0.211 & -0.42 & -0.265 & 0.12 & -0.316 & 0.349 & 1 & & & & & & & \\
\hline Number of grain & 0.295 & -0.507 & 0.25 & 0.195 & $-\mathbf{- 0 . 5 5 8}$ & -0.017 & -0.146 & -0.459 & -0.182 & 0.73 & 1 & & & & & & \\
\hline \multicolumn{18}{|l|}{ rows per ear } \\
\hline Spindle diameter & 0.549 & -0.073 & 0.38 & 0.002 & -0.227 & -0.403 & 0.297 & -0.517 & 0.417 & 0.859 & 0.565 & 1 & & & & & \\
\hline Seed length & -0.25 & 0.065 & -0.579 & 0.093 & -0.051 & 0.371 & -0.421 & 0.537 & 0.047 & 0.328 & 0.095 & -0.071 & 1 & & & & \\
\hline Seed width & -0.383 & 0.266 & -0.227 & 0.014 & 0.442 & -0.078 & 0.136 & 0.494 & 0.342 & -0.218 & -0.634 & -0.219 & 0.308 & 1 & & & \\
\hline Seed thickness & 0.16 & 0.183 & -0.128 & -0.192 & 0.327 & -0.04 & 0.344 & 0.046 & -0.037 & -0.292 & -0.314 & -0.19 & -0.42 & -0.021 & 1 & & \\
\hline Thousand-Kernel weight & -0.023 & 0.379 & -0.312 & 0.236 & 0.318 & 0.161 & 0.226 & 0.486 & 0.208 & 0.304 & -0.003 & 0.013 & 0.563 & 0.207 & 0.328 & 1 & \\
\hline Hectoliter weight & -0.492 & 0.475 & -0.481 & 0.049 & 0.332 & 0.165 & -0.03 & 0.896 & 0.289 & -0.228 & -0.463 & -0.466 & 0.579 & 0.528 & 0.16 & 0.611 & 1 \\
\hline
\end{tabular}

Values in bold are different from 0 with a significance level $\alpha=0.05$.

Table 5. First six components from the PCA analysis of 17 quantitative and quality traits

\begin{tabular}{lllllll}
\hline & F1 & F2 & F3 & F4 & F5 & F6 \\
\hline Moisture & 4.511 & 0.437 & 0.137 & 31.685 & 1.047 & 7.784 \\
Seed oil & 4.837 & 12.567 & 0.087 & 0.967 & 0.043 & 19.982 \\
Ash content & 7.274 & 9.645 & 2.686 & 4.921 & 0.708 & 2.816 \\
Seed protein & 0.019 & 9.228 & 2.318 & 13.675 & 15.444 & 8.678 \\
pH. & 6.414 & 0.454 & 4.595 & 8.173 & 0.029 & 10.994 \\
L* & 1.831 & 15.237 & 0.618 & 6.038 & 0.376 & 12.471 \\
$\mathrm{a}^{*}$ & 0.407 & 18.970 & 3.743 & 2.804 & 0.988 & 0.084 \\
$\mathrm{~b}^{*}$ & 16.156 & 0.203 & 2.352 & 0.437 & 0.192 & 0.971 \\
Ear length & 0.092 & 18.824 & 1.299 & 0.995 & 11.631 & 0.183 \\
Ear diameter & 5.912 & 2.542 & 19.662 & 2.814 & 0.061 & 1.772 \\
Number of grain rows per ear & 10.429 & 0.653 & 10.670 & 0.001 & 7.464 & 0.026 \\
Spindle diameter & 9.401 & 4.156 & 4.451 & 6.809 & 5.302 & 0.242 \\
Seed length & 4.049 & 0.722 & 26.502 & 0.004 & 0.506 & 0.042 \\
Seed width & 8.078 & 2.336 & 0.000 & 0.230 & 20.000 & 5.634 \\
Seed thickness & 0.935 & 0.498 & 9.313 & 11.115 & 18.741 & 23.873 \\
Thousand-Kernel weight & 4.251 & 2.660 & 8.735 & 9.325 & 17.132 & 1.140 \\
Hectoliter weight & 15.404 & 0.866 & 2.831 & 0.006 & 0.336 & 3.309 \\
Eigenvalue & 5.003 & 3.425 & 2.706 & 2.043 & 1.212 & 0.767 \\
Variability (\%) & 29.430 & 20.149 & 15.920 & 12.016 & 7.127 & 4.513 \\
Cumulative \% & 29.430 & 49.579 & 65.499 & 77.515 & 84.642 & 89.155 \\
\hline
\end{tabular}




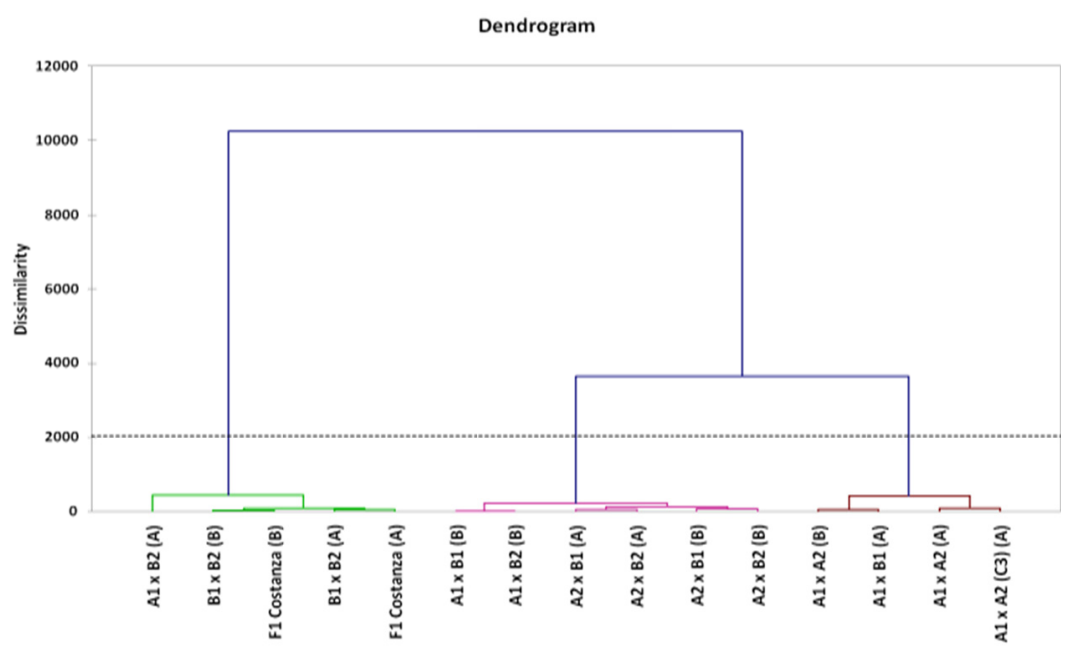

Figure 1. Dendrogram using agglomerative hierarchical clustering (AHC) for maize crosses based on 17 quantitative and quality traits

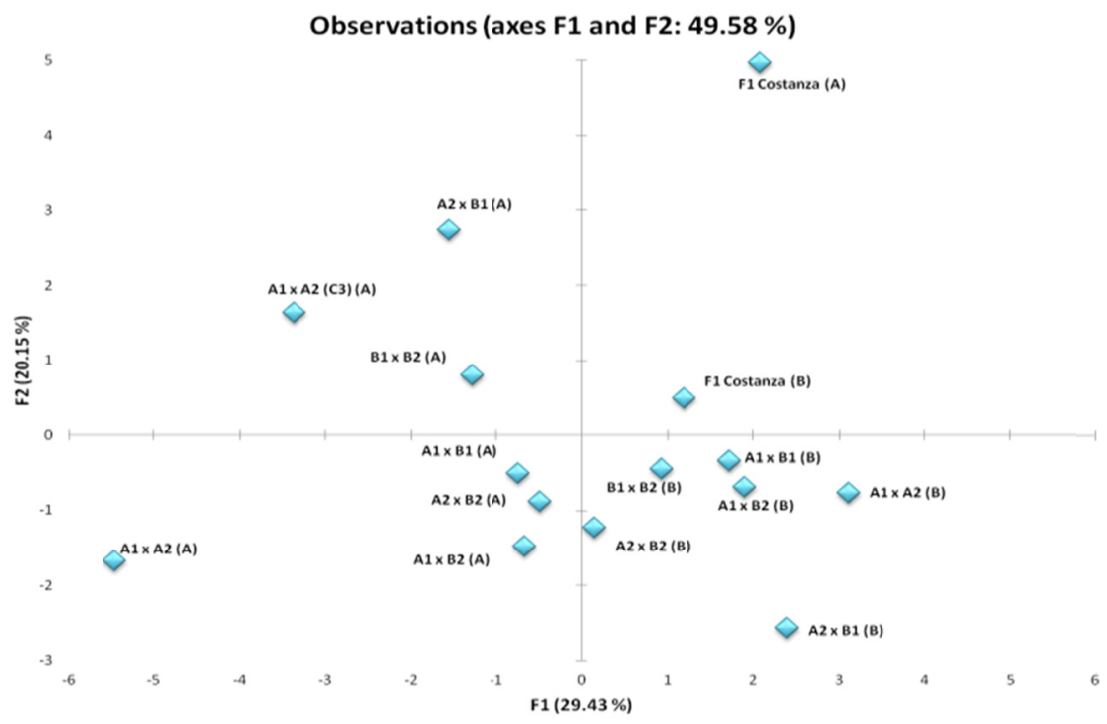

Figure 2. Principal Component Analysis of 17 quantitative and quality traits

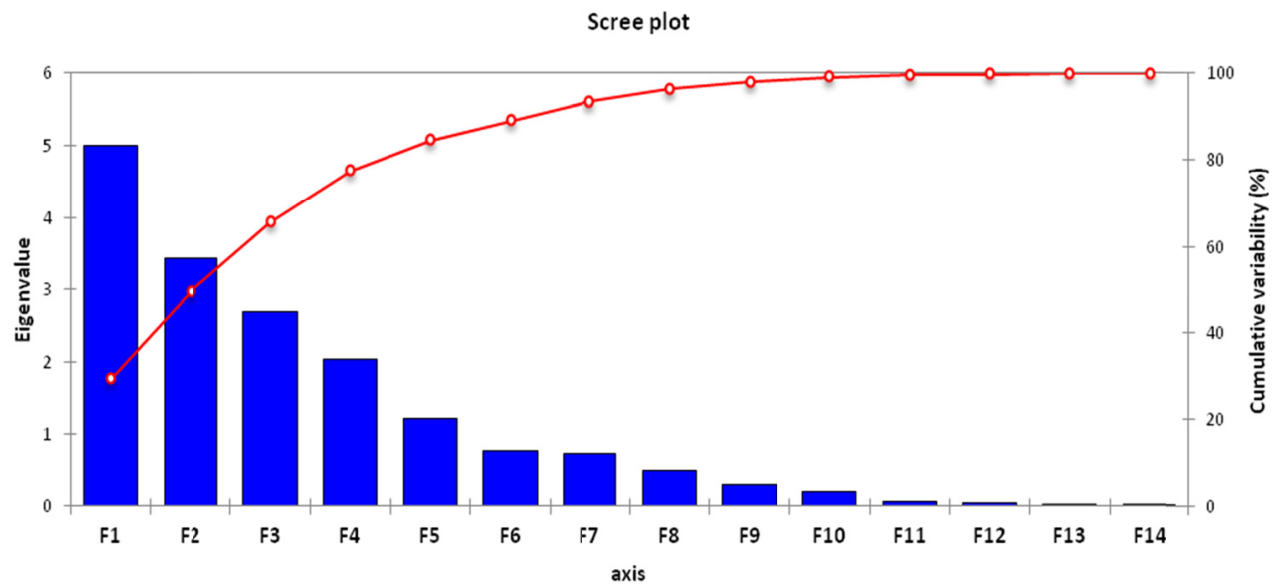

Figure 3. Screen plot of eigenvalues obtained from the PCA process for 17 quantitative and quality traits 


\subsection{Molecular Analysis With ISSR Markers}

A total of 64 polymorphic bands were obtained from the 6 primers. $100 \%$ of all loci were polymorphic. Gene diversity ranged from 0.268 to 0.383 and Shannon Index (I) from 0.320 to 0.567 (Table 6). In other studies, polymorphism was found over $70 \%$ for maize populations (Carvalho, Ruas, Ruas, Ferreira, \& Moreira, 2002; Žiarovska et al., 2013) or near 70\% for maize inbred lines (Idris, Hamza, Yagoub, Ibrahim \& El-Amin, 2012). It is possible that differences in such genetic materials may be due to polymorphism that acts as dominant genetic markers in case of populations (Sperisen \& Bücher, 1998; Žiarovska et al., 2013).

The first two coordinates of the PCA (Figure 4) represented only the $34.49 \%$ of the total heterogeneity among the maize crosses, while the first coordinate explained $18.49 \%$ of the variation. The distances on the PCA are corresponsive to the genetic distances. The F1 Costanza checks were placed on the same spot in PCA plot. On the other hand, the six newly-developed crosses evaluated in different environments showed measurable distances between identical lines. These distances indicate genotype-environment interactions. Genetic differentiation was observed between the six newly-developed crosses grown in agronomically contrasting environments (A and B). Generally, genetic differentiation can be attributed to the effect of both abiotic and biotic environmental factors on distribution patterns and populations genetic structures, as measured by random dominant markers (Odat, Jetschke, \& Hellwig, 2004, Abraham et al., 2015).

Table 6. Polymorphic bands, polymorphism percentage (\%), shannon index (I), Gene Diversity (GD), based on six primers in ISSR analysis

\begin{tabular}{lllll}
\hline Primer name & Polymorphic Bands & Polymorphism Percentage (\%) & Shannon Index (I) & Gene Diversity (GD) \\
\hline UBC834 & 9 & 100 & 0.417 & 0.277 \\
UBC824 & 9 & 100 & 0.376 & 0.268 \\
UBC841 & 7 & 100 & 0.415 & 0.282 \\
UBC807 & 19 & 100 & 0.567 & 0.383 \\
UBC811 & 12 & 100 & 0.522 & 0.365 \\
UBC827 & 8 & 100 & 0.32 & 0.232 \\
Mean & 10.66 & 100 & 0.436 & 0.301 \\
\hline
\end{tabular}

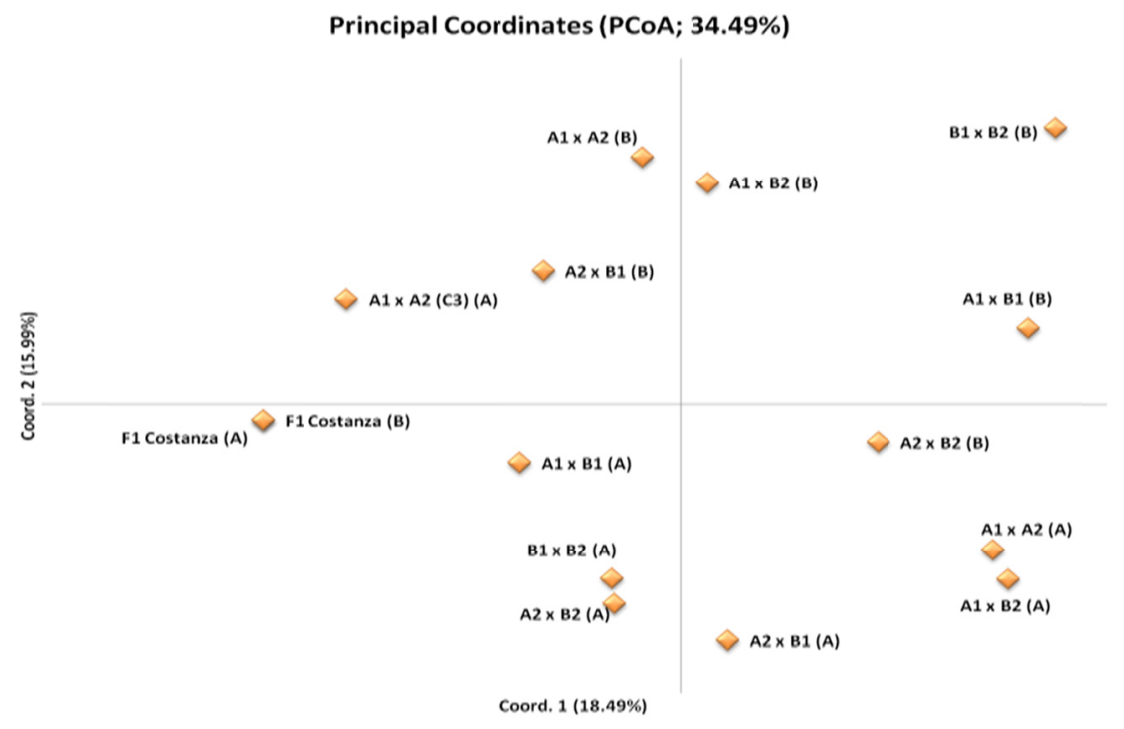

Figure 4. PCA analysis of genetic diversity of maize crosses

\section{Conclusions}

According to PCA analysis, the six newly-developed crosses, which were evaluated in different environments, showed measurable distances between the identical lines $(\mathrm{B} 1 \times \mathrm{B} 2$ (A) and $\mathrm{B} 1 \times \mathrm{B} 2$ (B)), suggesting 
genotype-environment interaction. Also, cluster analysis showed that some crosses are grouped in separate and distinct clusters, indicating that dissimilar developmental environments may cause changes in quantitative traits. This may be due to the origin of the selected lines, since they were developed in different locations. Lines developed in the same location gave crosses that had similar behavior in the two location. Also, it is clear that a kind of gene fixation is apparent from the $\mathrm{C} 3$ cycle in $\mathrm{A} 1 \times \mathrm{A} 2$ cross, since it is close (and similar) to the $\mathrm{C} 4 \mathrm{cross}$. Crosses including A2 line showed a greater stability in both environments.

\section{Acknowledgements}

This research has been partly co-financed by the European Union (European Social Fund-ESF) and Greek national funds through the Operational Program "Education and Lifelong Learning" of the National Strategic Reference Framework (NSRF)-Research Funding Program: Heracleitus II. Investing in knowledge society through the European Social Fund.

\section{References}

Abraham, E. M., Ganopoulos, I., Giagourta, P., Osathanunkul, M., Bosmali, I., Tsaftaris, A., ... Madesis, P. (2015). Genetic Diversity of Lotus corniculatus in Relation to Habitat Type Species Composition and Species Diversity. Biochemical Systematics and Ecology, 63, 59-67. https://doi.org/10.1016/j.bse.2015. 09.026

American Association of Cereal Chemists. (1983a). International Approved Methods (Method 08-01.01). Ash-Basic Method.

American Association of Cereal Chemists. (1983b). International Approved Methods (Method 44-15.02). Moisture-Air-Oven Methods.

American Association of Cereal Chemists. (1983c). International Approved Methods (Method 46-12.01). Crude Protein-Kjeldahl Method. Boric Acid Modification.

American Association of Cereal Chemists. (1983d). International Approved Methods (Method 30-25.01). Crude Fat in Wheat, Corn and Soy Flour, Feeds and Mixed Feeds.

Borrás, L., Zinselmeier, C., Senior, M. L., Westgate, M. E., \& Muszynski, M. G. (2009). Characterization of Grain-Filling Patterns in Diverse Maize Germplasm. Crop Science, 49, 999-1009. https://doi.org/10.2135/ cropsci2008.08.0475

Bredemeijer, G. M. M., Arens, P., Wouters, D., Visser, D., \& Vosman, B. (1998). The use of Semi-automated Fluorescent Microsatellite Analysis for Tomato Cultivar Identification. Theoretical and Applied Genetics, 97, 584-590. https://doi.org/10.1007/s001220050934

Carvalho, V. P., Ruas, P. M., Ruas, C. F., Ferreira, J. M.,\& Moreira, R. M. P. (2002). Assessment of Genetic Diversity in Maize (Zea mays L.) Landraces Using Inter Simple Sequence Repeat (ISSR) Markers. Crop Breeding and Applied Biotechnology, 2, 557-568. https://doi.org/10.12702/1984-7033.v02n04a09

Doyle, J. J., \& Doyle, J. L. (1987). A rapid DNA isolation procedure for small quantities of fresh leaf tissue. Phytochemical Bulletin, 19, 11-15.

Duvick, D. N., \& Cassman, K. G. (1999). Post-green revolution trends in yield potential of temperate maize in the north-central United States. Crop Science, 39, 1622-1630. https://doi.org/10.2135/cropsci1999. $3961622 x$

Duvick, D. N. (2005). Genetic progress in yield of United States maize (Zea mays L.). Maydica, 50, $193-202$.

Ezzat, E. M., Ali, M. A., \& Mahmoud, A. M. (2010). Agronomic Performance, Genotype x Environment Interactions and Stability Analysis of Grain Sorghum (Sorghum bicolor L. Moench). Asian Journal of Crop Science, 2, 250-260. https://doi.org/10.3923/ajcs.2010.250.260

Fasoula, D. A., \& Fasoula, V. A. (2005). Bridging the Productivity Gap Between Maize Inbreds and Hybrids by Replacing Gene and Genome Dichotomization with Gene and Genome Integration. Maydica, 50, 49-61.

Fasoula, V. A. (2006). A novel equation paves the way for an everlasting revolution with cultivars characterized by high and stable crop yield and quality. Proceedings of the 11th National Hellenic Conference in Genetics and Plant Breeding (pp. 7-14). Greece.

Fasoula, V. A. (2013). Prognostic Breeding: A new paradigm for crop improvement. In J. Janick (Ed.), Plant breeding reviews (Vol. 37. pp. 297-347). John Wiley \& Sons. https://doi.org/10.1002/9781118497869.ch6

Fasoulas, A. C. (1973). A New Approach to Breeding Superior Yielding Varieties (Pub. 3, Department of 
Genetics and Plant Breeding, Aristotle University of Thessaloniki, Greece).

Fasoulas, A. C. (1974). Evolution of Genetic System (Pub. 4, Department of Genetics and Plant Breeding, Aristotle University of Thessaloniki, Greece).

Fasoulas, A. C. (1988). The Honeycomb Methodology of Plant Breeding (Department of Genetics and Plant Breeding, Aristotle University of Thessaloniki, Greece).

Fasoulas, A. C. (1993). Principles of crop breeding (Department of Genetics and Plant Breeding, Aristotle University of Thessaloniki, Greece).

Flint-Garcia, S. A., Bodnar, A. L. \& Scott, M. P. (2009). Wide Variability in Kernel Composition, Seed Characteristics and Zein Profiles Among Diverse Maize Inbreds. Landraces and Teosinte. Theoretical and Applied Genetics, 119, 1129-1142. https://doi.org/10.1007/s00122-009-1115-1

Gilbert, J. E., Lewis, R. V., Windson, M. J., \& Caligari, P. D. S. (1999). Developing an Appropriate Strategy to Assess Genetic Variability in Plant Germplasm Collections. Theoretical and Applied Genetics, 98, 1125-1131. https://doi.org/10.1007/s001220051176

Godwin, I. D., Aitken, E. A. B., \& Smith, L. W. (1997). Application of Inter-Simple Sequence Repeat (ISSR) Markers to Plant Genetics. Electrophoresis, 18, 1524-1528. https://doi.org/10.1002/elps.1150180906

Hafiz, S. B. M., Jehanzeb, F., Ejaz-ul-Hasan, Tahira, B., \& Tariq, M. (2015). Cluster and principle component analyses of maize accessions under normal and water stress conditions. Journal of Agricultural Sciences, 60(1), 33-48.

Huang, J. C., \& Sun, M. (2000). Genetic Diversity and Relationships of Sweet Potato and its Wild Relatives in Ipomoea Series Batatas (Convolvulaceae) as Revealed by Inter-Simple Sequence Repeat (ISSR) and Restriction Analysis of Chloroplast DNA. Theoretical and Applied Genetics, 100, 1050-1060. https://doi.org/10.1007/s001220051386

Idris, A. E., Hamza, N. B., Yagoub, S. O., Ibrahim, A. I. A., \& El-Amin, H. K. A. (2012). Maize (Zea mays L.) Genotypes Diversity Study by Utilization of Inter-Simple Sequence Repeat (ISSR) Markers. Australian Journal of Basic and Applied Sciences, 6(10), 42-47.

Iezzoni, A. F., \& Pritts, M. P. (1991). Applications of Principal Component Analysis to Horticultural Research. HortScience, 26, 334-338.

Ipsilandis, C. G., \& Koutsika-Sotiriou, M. (2000). The Combining Ability of Recombinant S-Lines Developed from an F-2 Maize Population. Journal of Agricultural Science, Cambridge, 134, 191-198. https://doi.org/ $10.1017 / \mathrm{S} 0021859699007406$

Jaradat, A. A., \& Goldstein, W. (2013). Diversity of maize kernels from a breeding program for protein quality: I. physical, biochemical, nutrient, and color traits. Crop Science, 53, 956-976. https://doi.org/10.2135/ cropsci2012.07.0437

Jones, R. J., \& Simmons, S. R. (1983). Effect of altered source-sink ratio on growth of maize kernels. Crop Sci., 23, 129-134. https://doi.org/10.2135/cropsci1983.0011183X002300010038x

Kaiser, H. F. (1958). The Varimax Criterion for Analytic Rotation in Factor Analysis. Psychometrika, 23, 187-200. https://doi.org/10.1007/BF02289233

Kaur, S., Singh, N., \& Rana. J. C. (2010). Amaranthus hypondriacus and Amaranthus caudatus germplasm: Characteristics of Plants, Grain, and Flours. Food Chemistry, 123, 1227-1234. https://doi.org/10.1016/ j.foodchem.2010.05.091

Khodarahmpour, Z. (2012). Morphological Classification of Maize (Zea mays L.) Genotypes in Heat Stress Condition. Journal of Agricultural Science, 4(5), 31-40. https://doi.org/10.5539/jas.v4n5p31

Koutsika-Sotiriou, M. (1999). Hybrid Seed Production in Maize. In A. S. Basra (Ed.), Heterosis and Hybrid Seed Production in Agronomic Crops (pp. 25-64). New York: Food Products Press.

Métais, I., Aubry, C., Hamon, B., Jalouzot, R., \& Peltier, D. (2000). Description and Analysis of Genetic Diversity Between Commercial Bean Lines (Phaseolous vulgaris L.). Theoretical and Applied Genetics, 101, 1207-1214. https://doi.org/10.1007/s001220051599

Mohammadi, S. A., \& Prasanna, B. M. (2003). Analysis of Genetic Diversity in Crop Plants-Calient Statistical Tools and Considerations. Crop Science, 43, 1235-1248.

Nuss, E. T., \& Tanumihardjo, S. A. (2010). Maize: A paramount staple crop in the context of global nutrition. 
Comprehensive Reviews in Food Science and Food Safety, 9, 417-436.

Odat, N., Jetschke, G., \& Hellwig, F. H. (2004). Genetic Diversity of Ranunculus acris L. (Ranunculaceae) Populations in Relation to Species Diversity and Habitat to Species Diversity and Habitat Type in Grassland Communities. Molecular Ecology, 13, 1251-1257. https://doi.org/10.1111/j.1365-294X.2004.02115.x

Peakall, R., \& Smouse, P. E. (2012). GenAlEx 6.5: Genetic Analysis in Excel. Population Genetic Software for Teaching and Research-an update. Bioinformatics, 28, 2537-2539. https://oi.org/10.1093/bioinformatics/ bts460

Peeters, J. P., \& Martinelli, J. A. (1989). Hierarchical Cluster Analysis as a Tool to Managevariation in Germplasm Collections. Theoretical and Applied Genetics, 78, 42-48.

Prasad, M., Varshney, R. K., Roy, J. K., Balyan, H. S., \& Gupta, P. K. (2000). The Use of Microsatellies for Detecting DNA Polymorphism, Genotype Identification and Genetic Diversity in wheat. Theoretical and Applied Genetics, 100, 584-592. https://doi.org/10.1007/s001229900102

Prevost, A., \& Wilkinson, M. J. (1999). A New System of Comparing PCR Primers Applied to SSR Fingerprinting of Potato Cultivars. Theoretical and Applied Genetics, 98, 107-112. https://oi.org/10.1007/ s001220051046

Rahman, S., Mukul, M. D. M., Quddus, T., Hassan, L., \& Haque, M. D. A. (2015). Assessing Genetic Diversity of Maize (Zea mays L.) Genotypes for Agronimic Traits. Research in Agriculture Livestock and Fisheries, 2(1), 53-61.

Rakonjac, V., Aksic, M. F., Nikolic, D., Milatovic, D., \& Colic, S. (2010). Morphological Characterization of 'Oblacinska' sour Cherry by Multivariate Analysis. Scientia Horticulturae, 125, 679-684. https://doi.org/ 10.1016/j.scienta.2010.05.029

Salimath, S. S., de Oliveira, A. C., Godwin, I. D., \& Bennetzen, J. L. (1995). Assessment of Genome Origins and Genetic Diversity in the Genus Eleusine with DNA Markers. Genome, 38, 757-763. https://oi.org/10.1139/ g95-096

Shehzad, T., Okuizumi, H., Kawase, M., \& Okuno, K. (2009). Development of SSR-Based Sorghum (Sorghum bicolor L. Moench) Diversity Research set of Germplasm and its Evaluation by Morphological Traits. Genetic Resources and Crop Evolution, 56, 809-827. https://doi.org/10.1007/s10722-008-9403-1

Sperisen, C., \& Bücher, U. (1998). Cloning of Random Amplified Polymorphic DNA (RAPD) to Generate Codominant Genetic Marker. In A. Karp, P. G. Issac, \& D. S. Ingram (Eds.), Molecular Tools for Screening Biodiversity (pp. 217-222). Chapman \& Hall, London. https://doi.org/10.1007/978-94-009-0019-6_43

Steel, R. G. D., \& Torie, H. (1980). Principles and procedures of statistics (2nd ed.). Biometrical Approach, New York, McGraw-Hill. https://doi.org/10.1007/978-94-009-0019-6 43

Tollenaar, M., \& Lee, E. A. (2002). Yield potential, yield stability and stress tolerance in maize. Field Crops Research, 75, 161-69. https://doi.org/10.1016/S0378-4290(02)00024-2

Tollenaar, M., Ying, J., \& Duvick, D. N. (2000). Genetic gain in corn hybrids. Proceedings 55th Annual Research Conference on Corn and Sorghum, Chicago, IL (pp. 53-62). American Seed Trade Association: Washington, DC.

Warburton, M. L., Xianchun, X., Crossa, J., Franco, J., Mel Chin-Ger, A. E., Frisch, M., ... Hoisington, D. (2002). Genetic Characterization of CIMMYT Inbred Maize Lines and Open Pollinated Populations Using Large Scale Fingerprinting Methods. Crop Science, 42, 1832-1840. https://doi.org/10.2135/ cropsci2002.1832

Watson, S. A. (2003). Description, Development, Structure and Composition of the Corn Kernel. In P. J. White \& L. A. Johnson (Eds.), Corn: Chemistry and Technology (2nd ed.) American Association of Cereal Chemists, St. Paul.

Yang, W., de Oliveira A. C., Godwin, I., Schertz, K., \& Bennetzen, J. L. (1996). Comparison of DNA Marker Technologies in Characterizing Plant Genome Diversity: Variability in Chinese Sorghums. Crop Science, 36 , 1669-1676. https://doi.org/10.2135/cropsci1996.0011183X003600060042x

Žiarovská, J., Senková, S., Bežo, M., Ražná, K., Masnica, M., \& Labajová, M. (2013). ISSR Markers as a Tool to Distinguish Idt and SSS Populations of Zea mays L. Journal of Central European Agriculture, 14(2), 489-499. https://doi.org/10.5513/JCEA01/14.2.1227 


\section{Copyrights}

Copyright for this article is retained by the author(s), with first publication rights granted to the journal.

This is an open-access article distributed under the terms and conditions of the Creative Commons Attribution license (http://creativecommons.org/licenses/by/4.0/). 